\title{
DIABETES MELLITUS AND GOUT BLOOD SUGAR AND PLASMA INSULIN RESPONSES TO ORAL GLUCOSE IN NORMAL WEIGHT, OVERWEIGHT, AND GOUTY PATIENTS*
}

\author{
BY
J. A. BOYLE, ${ }^{1}$ M. McKIDDIE, K. D. BUCHANAN, ${ }^{2}$ M. K. JASANI, ${ }^{3}$ H. W. GRAY, I. M. D. JACKSON, AND W. WATSON BUCHANAN
From the Centre for Rheumatic Diseases, Glasgow, and the Diabetic Unit and University Department of Medicine, Royal Infirmary, Glasgow

Dr. Robert Whytt of Edinburgh first suggested in 1768 the association of diabetes mellitus and gouty arthritis (Whytt, 1768) and Charcot (1881) postulated that the inheritance of a common underlying character could lead to the development of either gouty arthritis or diabetes mellitus. The position to-day, however, regarding the association between these two diseases is still not certain. Present evidence does not support an increased prevalence of gout in patients with diabetes mellitus. Joslin, Root, White, and Marble (1952), in Boston, found only one gouty patient in 1,500 patients with diabetes mellitus. In London, Beckett and Lewis (1960) described eight patients with gout in the first 1,000 diabetic subjects whom they studied, and considered that this gave no support to a genetic association between the two conditions.

Although hyperuricaemia is found in uncontrolled diabetes when keto-acidosis is present (Padova and Bendersky, 1962), the serum uric acid levels would appear to be low in patients with controlled

*Presented to the VI European Congress of Rheumatology, Lisbon, in October, 1967.

${ }^{1}$ Harkness Travelling Fellow, Department of Human Biochemical Genetics, National Institute of Arthritis and Metabolic Diseases, National Institutes of Health, Bethesda, Maryland, U.S.A.

${ }^{2}$ Department of Medicine, Queen's University of Belfast, Royal

Victoria Hospital, Belfast, Northern Ireland.

${ }^{3}$ CIBA Laboratories Ltd., Horsham, Sussex, England. diabetes mellitus (Beckett and Lewis, 1960; Mikkelsen, 1965).

Studies of gouty patients have revealed a variable prevalence of diabetes mellitus. Umber (1914) reported a prevalence of 5.4 per cent. in 278 patients with gout, and other estimates range from 3 to 10 per cent. (Kuzell, Schaffarzick, Naugler, Koets, Mankle, Brown, and Champlin, 1955; Bartels, Balodimos, and Corn, 1960; Bendersky and Kreithen, 1962; Whitehouse and Cleary, 1966). In addition, Weiss, Segaloff, and Moore (1957) found that 28 per cent. of 143 gouty patients had an abnormal oral glucose tolerance test using rigid criteria of a normal glucose tolerance test. Against these reports is the experience of Talbott in Buffalo who encountered only three patients with diabetes mellitus in his whole experience of patients with gout (Talbott, 1964).

The present study was undertaken to investigate carbohydrate and insulin metabolism in patients with gout. Two groups of patients, one with normal body weight, and one matched for body weight with the gouty patients, served as controls. In a second approach to this problem, the effect of artificial elevation of serum uric acid values by ribonucleic acid (RNA) feeding on blood sugar and plasma insulin responses to an oral glucose load was studied.

BLOOD SUGAR AND PLASMA INSULIN RESPONSES TO $50 \mathrm{~g}$. ORAL GLUCOSE IN LEA

\begin{tabular}{|c|c|c|c|c|c|c|}
\hline \multirow{2}{*}{ Clinical Groups } & \multirow{2}{*}{$\begin{array}{l}\text { No. in } \\
\text { Group }\end{array}$} & \multirow{2}{*}{$\begin{array}{l}\text { Age } \\
\text { (yrs) }\end{array}$} & \multirow{2}{*}{$\begin{array}{l}\text { Per cent. } \\
\text { Ideal weight }\end{array}$} & \multicolumn{3}{|r|}{ Blood S蛕ar } \\
\hline & & & & Fasting & $30 \mathrm{~min}$. & 60 minse \\
\hline (1) Ideal Bodyweight Controls & 21 & $50 \pm 13$ & $101 \pm 13$ & $90 \pm 10$ & $139 \pm 19$ & $131 \pm 30 \mathrm{C}$ \\
\hline (2) Overweight Controls & 10 & $40 \pm 18$ & $140 \pm 15$ & $89 \pm 12$ & $138 \pm 19$ & $162 \pm 36$ \\
\hline (3) Gouty Subjects & 13 & $55 \pm 13$ & $134 \pm 16$ & $97 \pm 8$ & $154 \div 34$ & $172 \pm 440$ \\
\hline \multicolumn{4}{|l|}{$\begin{array}{r}P \text { values by " } t \text { "-test Groups } 1 \text { and } 3 \\
\text { Groups } 2 \text { and } 3\end{array}$} & $\begin{array}{l}<0.025 \\
<0.05\end{array}$ & & $<0.05 \frac{\text { 吊 }}{\frac{\mathbb{D}}{\mathrm{Q}}}$ \\
\hline All values shown are mean \pm S.D. & Percentage i & from Do & a Geigy Scient & & & 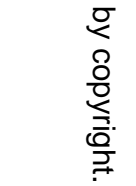 \\
\hline
\end{tabular}




\section{Material and Methods}

Blood Sugar and Plasma Insulin Responses to an Oral Glucose Load (Table I).-Thirteen patients with chronic primary gout arthritis were studied. The serum uric acid level ranged from 6.8 to $10.4 \mathrm{mg}$. per cent. at the time of study, and all patients had discontinued treatment with colchicine, uricosuric drugs, allopurinol, and any other drugs currently being taken for at least one week before the study. All patients were hospitalized for at least one week before study and were receiving an ordinary diet. The mean age of these patients was $54 \cdot 5$ years (range 35 to 83 ). The mean percentage ideal weight (percentage of ideal weight for height and sex taken from Documenta Geigy) was 134 (range 92 to 150).

The first group of 21 control patients suffered from either mild rheumatoid or osteoarthritis; their mean age was 50 years (range 20 to 70 ). Their percentage ideal weight was 101.4 (range 70 to 120). Analgesic and any other therapy currently being taken had been discontinued one week before the study. All had been in-patients for at least one week before they were studied. None had ever received corticosteroid therapy.

In the second group of ten control patients the diagnosis of simple obesity had been established. They had been selected to match the gouty subjects for body weight. Their mean age was $40 \cdot 1$ years (range 22 to 66 ) and their mean percentage ideal weight was 140 (range 120 to 160). None of these patients had been given any drugs one week before the study.

Blood Sugar and Plasma Insulin Responses to an Oral Glucose Load after RNA Feeding (Table II).--Seven patients were studied. In five a diagnosis of osteoarthritis has been made and oral glucose tolerance tests were normal. In two a mild diabetic abnormality of the oral glucose tolerance test was present, in that the blood sugar levels at 120 minutes after an oral $50 \mathrm{~g}$. glucose load were greater than $120 \mathrm{mg}$. per cent.: these two patients both had mild rheumatoid arthritis. All seven patients stopped all drug therapy one week before and during the study. $4 \mathrm{~g}$. powdered RNA was given twice daily by mouth for 3 days. The rise in serum uric acid induced by this procedure is shown in Table II (overleaf).
The method of patient selection in this study was as follows. Control patients were included in the study on the basis of their body weight without prior knowledge of whether or not they had glycosuria. The thirteen gouty patients were studied consecutively as they were admitted to hospital, irrespective of the presence of glycosuria or of body weight. All gouty patients who were seen for the first time at the out-patients department while this study was in progress were admitted for investigation.

Oral glucose tolerance tests were carried out in the fasting state using a $50 \mathrm{~g}$. dose of glucose. Venous blood samples were taken in the fasting state, and at 30,60 , 90 , and $120 \mathrm{~min}$. after the dose of glucose. Blood sugar was estimated by the ferricyanide method on the Technicon Auto-Analyzer, and plasma insulin was measured by the method of Hales and Randle (1963). Results of the insulin assay in this laboratory with regard to sensitivity and specificity have been presented elsewhere (Buchanan and McKiddie, 1967).

Serum uric acid was measured by the Auto-Analyzer method N22.

In subjects given RNA the blood sugar and plasma insulin responses to the glucose load were measured immediately before and after 3 days of RNA feeding.

Tests of significance between means were calculated by Student's " $t$ " test.

\section{Results}

Blood Sugar and Plasma Insulin Responses to an Oral Glucose Load (Table I).- The measurement of fasting blood sugar (range 91-115 mg. per cent.) and fasting insulin (range 18 to $50 \mu$ units per ml.) on four successive days in six fasting patients gave a standard error of the mean of 1.6 and 2.8 per cent. respectively, indicating a good standard of reproducibility.

Table I shows the mean values of blood sugar and plasma insulin in the thirteen patients with gout, the 21 normal weight control patients, and the ten overweight (i.e. weight-matched) control patients, fasting and at $30,60,90$, and $120 \mathrm{~min}$. after $50 \mathrm{~g}$. oral glucose load. The mean \pm the SD were significantly higher at fasting, and at 60 and $90 \mathrm{~min}$. in

I

CONTROLS (GROUP 1), OVER-WEIGHT CONTROLS (GROUP 2), AND GOUTY SUBJECTS (GROUP 3)

\begin{tabular}{|c|c|c|c|c|c|c|}
\hline \multicolumn{2}{|l|}{ (mg. per cent.) } & \multicolumn{5}{|c|}{ Plasma Insulin $(\mu \mathrm{U} / \mathrm{ml})}$. \\
\hline $90 \mathrm{~min}$. & $120 \mathrm{~min}$. & Fasting & $30 \mathrm{~min}$. & $60 \mathrm{~min}$. & $90 \mathrm{~min}$. & $120 \mathrm{~min}$. \\
\hline $110 \pm 34$ & $91 \pm 28$ & $23 \pm 14$ & $107 \pm 44$ & $103 \pm 55$ & $71 \pm 39$ & $48 \pm 36$ \\
\hline $146 \pm 47$ & $119 \pm 31$ & $25 \pm 8$ & $98 \pm 31$ & $114 \pm 35$ & $96 \pm 40$ & $75 \pm 44$ \\
\hline $144 \pm 35$ & $106 \pm 24$ & $38 \pm 38$ & $135 \pm 98$ & $136 \pm 70$ & $115 \pm 70$ & $77 \pm 60$ \\
\hline$<0.01$ & & & & & $<0.025$ & \\
\hline
\end{tabular}


the gouty patients than those in the normal weight controls. The response of the overweight patients was similar to that of the patients with gout. The mean levels after oral glucose loading were not only similar in the gouty and overweight subjects, but there was no trend for one group to have higher values than the other. The fasting blood sugar levels of patients with gout was, however, slightly higher than that of the overweight controls, and this just reached significance at the 5 per cent. level (Table I).

The plasma insulin responses after oral glucose loading in the three groups are also shown in Table I. There was a very wide scatter of results in the gouty patients; one in particular showed an enormous response in plasma insulin level to the glucose load, from $160 \mu \mathrm{U}$ per $\mathrm{ml}$. he rose to 450 at $30 \mathrm{~min}$. and then fell to 220 at $120 \mathrm{~min}$. In this patient the blood sugar response was normal.

The mean plasma insulin response in normal weight controls were slightly lower than in patients with gout, but were only significantly lower $(\mathrm{P}<$ 0.025 ) at 90 minutes after glucose. In other words, the data suggest that gouty subjects have a slightly delayed fall-off in plasma insulin response after glucose. A similar delay was seen in the overweight controls, who did not differ from the lean controls in their fasting and $30 \mathrm{~min}$. plasma insulin values, but had higher values at 60,90 , and $120 \mathrm{~min}$.
Blood Sugar and Plasma Insulin Responses to an Oral Glucose Load after RNA Feeding.-In five patients with a normal glucose tolerance test and in two with a mild diabetic abnormality (Cases 40 and 41) before RNA, no significant difference was noted in either the fasting blood sugar and plasma insulin or the response of these variables after glucose loading (Table II).

\section{Discussion}

These results show that blood sugar values after oral glucose loading are significantly higher in patients with gout than in normal weight control subjects. Taking a blood sugar value greater than $120 \mathrm{mg}$. per cent. to be abnormal 120 minutes after the oral administration of $50 \mathrm{~g}$. glucose, the data show that three of the 21 normal weight control patients and three of the thirteen gouty subjects were abnormal. In addition, patients with gout tended to have higher plasma insulin responses to glucose loading than normal weight controls, but such was the scatter in observations of plasma insulin levels that this tendency is significant only at the $90 \mathrm{~min}$. stage after the glucose loading. One might conclude from these observations that there was an abnormality of carbohydrate and perhaps of insulin metabolism in patients with gout, but the findings in the obese controls who were weight-matched with

TABLE II

BLOOD SUGAR AND PLASMA INSULIN RESPONSES TO $50 \mathrm{~g}$. ORAL GLUCOSE BEFORE AND AFTER RNA FEEDING FOR 3 DAYS IN SEVEN CONTROL SUBJECTS

\begin{tabular}{|c|c|c|c|c|c|c|c|c|c|c|c|c|}
\hline \multirow{2}{*}{$\begin{array}{l}\text { Patient } \\
\text { No. }\end{array}$} & \multirow{2}{*}{$\begin{array}{c}\text { RNA } \\
\text { Feeding }\end{array}$} & \multirow{2}{*}{$\begin{array}{c}\text { Uric Acid } \\
\text { (mg. per cent.) }\end{array}$} & \multicolumn{5}{|c|}{ Blood Sugar (mg. per cent.) } & \multicolumn{5}{|c|}{ Plasma Insulin $(\mu \mathrm{U} / \mathrm{ml})}$. \\
\hline & & & Fasting & $30 \mathrm{~min}$. & $60 \mathrm{~min}$. & $90 \mathrm{~min}$. & $120 \mathrm{~min}$. & Fasting & $30 \mathrm{~min}$. & $60 \mathrm{~min}$ & $90 \mathrm{~min}$. & $120 \mathrm{~min}$. \\
\hline 23 & $\begin{array}{l}\text { Before } \\
\text { After }\end{array}$ & $\begin{array}{l}3 \cdot 2 \\
7 \cdot 1\end{array}$ & $\begin{array}{l}78 \\
87\end{array}$ & $\begin{array}{l}128 \\
113\end{array}$ & $\begin{array}{l}82 \\
94\end{array}$ & $\begin{array}{r}78 \\
107\end{array}$ & $\begin{array}{l}88 \\
85\end{array}$ & 26 & $\begin{array}{l}112 \\
105\end{array}$ & $\begin{array}{r}108 \\
92\end{array}$ & $7^{*}$ & $\begin{array}{l}57 \\
46\end{array}$ \\
\hline 35 & $\begin{array}{l}\text { Before } \\
\text { After }\end{array}$ & $\begin{array}{l}3 \cdot 6 \\
5 \cdot 2\end{array}$ & $\begin{array}{l}85 \\
90\end{array}$ & $\begin{array}{l}160 \\
165\end{array}$ & $\begin{array}{l}156 \\
160\end{array}$ & $\begin{array}{l}134 \\
123\end{array}$ & $\begin{array}{l}88 \\
80\end{array}$ & $\begin{array}{l}17 \\
20\end{array}$ & $\begin{array}{l}145 \\
155\end{array}$ & $\begin{array}{l}130 \\
162\end{array}$ & $\begin{array}{l}105 \\
106\end{array}$ & $\begin{array}{l}30 \\
24\end{array}$ \\
\hline 37 & $\begin{array}{l}\text { Before } \\
\text { After }\end{array}$ & $\begin{array}{l}6 \cdot 6 \\
8 \cdot 8\end{array}$ & $\begin{array}{r}104 \\
85\end{array}$ & $\begin{array}{l}172 \\
167\end{array}$ & $\begin{array}{l}176 \\
158\end{array}$ & $\begin{array}{r}140 \\
84\end{array}$ & $\begin{array}{l}91 \\
70\end{array}$ & $\begin{array}{r}3 \\
12\end{array}$ & $\begin{array}{l}52 \\
73\end{array}$ & $\begin{array}{l}119 \\
106\end{array}$ & $\begin{array}{l}79 \\
43\end{array}$ & $\begin{array}{l}30 \\
13\end{array}$ \\
\hline 38 & $\begin{array}{l}\text { Before } \\
\text { After }\end{array}$ & $\begin{array}{l}3 \cdot 2 \\
6 \cdot 5\end{array}$ & $\begin{array}{l}78 \\
84\end{array}$ & $\begin{array}{l}154 \\
149\end{array}$ & $\begin{array}{l}154 \\
141\end{array}$ & $\begin{array}{l}128 \\
126\end{array}$ & $\begin{array}{l}82 \\
96\end{array}$ & $\begin{array}{l}7 \\
2\end{array}$ & $\begin{array}{l}179 \\
142\end{array}$ & $\begin{array}{r}101 \\
80\end{array}$ & $\begin{array}{l}65 \\
54\end{array}$ & $\begin{array}{l}20 \\
22\end{array}$ \\
\hline 39 & $\begin{array}{l}\text { Before } \\
\text { After }\end{array}$ & $\begin{array}{l}4 \cdot 1 \\
5 \cdot 8\end{array}$ & $\begin{array}{r}100 \\
88\end{array}$ & $\begin{array}{l}125 \\
142\end{array}$ & $\begin{array}{l}130 \\
130\end{array}$ & $\begin{array}{r}90 \\
120\end{array}$ & $\begin{array}{r}82 \\
100\end{array}$ & $\begin{array}{l}20 \\
25\end{array}$ & $\begin{array}{l}132 \\
242\end{array}$ & $\begin{array}{l}166 \\
173\end{array}$ & $\begin{array}{l}124 \\
124\end{array}$ & $\begin{array}{r}69 \\
137\end{array}$ \\
\hline$* 40$ & $\begin{array}{l}\text { Before } \\
\text { After }\end{array}$ & $\begin{array}{l}3 \cdot 3 \\
5 \cdot 1\end{array}$ & $\begin{array}{r}90 \\
106\end{array}$ & $\begin{array}{l}168 \\
180\end{array}$ & $\begin{array}{l}232 \\
200\end{array}$ & $\begin{array}{l}192 \\
160\end{array}$ & $\underline{157}+$ & $\begin{array}{l}15 \\
28\end{array}$ & $\begin{array}{r}60 \\
105\end{array}$ & $\begin{array}{l}148 \\
158\end{array}$ & $\begin{array}{l}135 \\
115\end{array}$ & $\begin{array}{l}98 \\
83\end{array}$ \\
\hline$* 41$ & $\begin{array}{l}\text { Before } \\
\text { After }\end{array}$ & $\begin{array}{l}6 \cdot 7 \\
9 \cdot 1\end{array}$ & $\begin{array}{l}86 \\
94\end{array}$ & $\begin{array}{l}150 \\
176\end{array}$ & $\begin{array}{l}192 \\
199\end{array}$ & $\begin{array}{l}182 \\
177\end{array}$ & $\begin{array}{l}162 \\
164\end{array}$ & $\begin{array}{r}13 \\
8\end{array}$ & $\begin{array}{r}78 \\
102\end{array}$ & $\begin{array}{l}170 \\
116\end{array}$ & $\begin{array}{r}100 \\
72\end{array}$ & $\begin{array}{l}133 \\
100\end{array}$ \\
\hline \multicolumn{2}{|c|}{$\begin{array}{l}\text { Mean } \\
\text { Before SD of Mean }\end{array}$} & $\begin{array}{l}4 \cdot 39 \\
1 \cdot 57\end{array}$ & $\begin{array}{l}88 \cdot 7 \\
10 \cdot 1\end{array}$ & $\begin{array}{r}151 \cdot 0 \\
18 \cdot 9\end{array}$ & $\begin{array}{r}160 \cdot 3 \\
47 \cdot 4\end{array}$ & $\begin{array}{r}134 \cdot 9 \\
42 \cdot 4\end{array}$ & $\begin{array}{r}107 \cdot 1 \\
35 \cdot 9\end{array}$ & $\begin{array}{r}14 \cdot 4 \\
7 \cdot 7\end{array}$ & $\begin{array}{r}108 \cdot 3 \\
47 \cdot 2\end{array}$ & $\begin{array}{r}134 \cdot 5 \\
27 \cdot 5\end{array}$ & $\begin{array}{l}96 \cdot 8 \\
26 \cdot 8\end{array}$ & $\begin{array}{l}62 \cdot 4 \\
41 \cdot 3\end{array}$ \\
\hline \multicolumn{2}{|c|}{$\begin{array}{l}\text { Mean } \\
\text { After SD of Mean }\end{array}$} & $\begin{array}{l}6 \cdot 8 \\
1 \cdot 63\end{array}$ & $\begin{array}{r}90 \cdot 5 \\
8 \cdot 1\end{array}$ & $\begin{array}{r}156 \cdot 0 \\
23 \cdot 4\end{array}$ & $\begin{array}{r}154 \cdot 5 \\
37 \cdot 7\end{array}$ & $\begin{array}{r}141 \cdot 0 \\
31 \cdot 3\end{array}$ & $\begin{array}{l}99 \cdot 2 \\
33 \cdot 6\end{array}$ & $\begin{array}{l}18 \cdot 3 \\
11 \cdot 3\end{array}$ & $\begin{array}{r}132 \cdot 0 \\
55 \cdot 6\end{array}$ & $\begin{array}{r}126 \cdot 7 \\
37 \cdot 2\end{array}$ & $\begin{array}{l}85 \cdot 6 \\
33 \cdot 9\end{array}$ & $\begin{array}{l}60 \cdot 7 \\
47 \cdot 0\end{array}$ \\
\hline
\end{tabular}

*Patients 40 and 41 had a slight diabetic abnormality of glucose tolerance test before RNA feeding. $\dagger$ Not measured in this patient. 
the gouty patients suggest that such a conclusion may not be valid. No significant differences were observed in the blood sugar response and plasma insulin levels after oral glucose loading between gouty patients and overweight subjects, nor was there a trend for one group to have an enhanced blood sugar or plasma insulin response.

One interpretation of these data which suggests itself is that there is an abnormality of carbohydrate and perhaps insulin metabolism in patients with gout and that this abnormality is a function of the obesity of these subjects rather than of the intrinsic abnormality associated with altered metabolism of purines causing hyperuricaemia. Tentative support for this conclusion comes from the finding that the blood sugar and plasma insulin responses to oral glucose are unaltered after the serum uric acid level has been raised by RNA feeding for 3 days. Moreover, both patients with gout (Brøchner-Mortensen, 1958) and patients with maturity-onset diabetes mellitus tend to be overweight, and the findings of some workers of an association between these diseases may simply reflect this fact. In epidemiological studies of Polynesian people, Prior and his associates (Prior and Davidson, 1966; Prior, Rose, Harvey, and Davidson, 1966) have described an increased prevalence of hyperuricaemia, gout, and diabetes mellitus of the maturity-onset type in overweight New Zealand Maoris.

Our data therefore suggest that gouty patients are to be compared with respect to the prevalence of diabetes mellitus and their carbohydrate and insulin metabolism with weight-matched control subjects. In only one study to our knowledge has such a comparison been made; Weiss, Segaloff, and Moore (1957) studied 143 gouty patients and compared their carbohydrate metabolism with 143 age and weight-matched controls. They found that forty of their patients with gout and 27 of their controls had an abnormal oral glucose tolerance test. On this basis they concluded that "the relationship between gout and elevated blood sugar appears to be more than a casual one". We do not feel that their data support their conclusion, since there is no significant difference between these results by a $\chi^{2}$ analysis $\left(\chi^{2}=3 \cdot 294 ; 0 \cdot 1<P<0 \cdot 2\right)$.

A surprising incidental finding was that the fasting plasma insulin values of the overweight control subjects was not higher than that of the lean controls.
Previous work (Bagdade, Bierman, and Porte, 1967) indicates that the fasting plasma insulin levels in obesity are higher than those in lean subjects. However, our overweight subjects did have higher plasma insulin values at 60,90 , and $120 \mathrm{~min}$. after taking glucose. Our fasting plasma insulin values might be explained by the older mean age of our lean controls, and also by the fact that our lean controls were not selected because of normal glucose tolerance, but simply as a comparable group for the gouty subjects. In a larger group of patients we have found higher fasting plasma insulin values in obese subjects as compared with lean controls with normal glucose tolerance, and indeed have found a positive correlation between the fasting plasma insulin values and the degree of obesity in obese subjects (McKiddie, Jackson, and Buchanan, unpublished observations).

In conclusion, this study has failed to demonstrate a disturbance of carbohydrate or insulin metabolism in patients with gout when due allowance is made for the fact that gouty patients tend to be overweight.

\section{Summary}

The possible association of abnormalities of oral glucose tolerance tests and gout have been explored.

Blood sugar levels after an oral $50 \mathrm{~g}$. glucose load and in the fasting state were significantly higher in patients with gout than in controls of normal body weight. Gouty subjects also tended to have higher plasmin insulin levels during the glucose tolerance test.

When the data in gouty patients were compared with the findings in obese subjects who were weightmatched, these differences were not evident.

When blood uric acid levels were artificially raised in normouricaemic individuals by RNA feeding, no change was noted in carbohydrate and insulin metabolism.

It is concluded that no significant disturbance of carbohydrate and insulin metabolism is associated with the metabolic defect causing hyperuricaemia in primary gout, if due allowance is made for the obesity which gouty patients often exhibit.

This study was supported by the Arthritis and Rheumatism Council for Research in Great Britain. One of us (MKJ) was in receipt of a CIBA clinical research fellowship.

\section{REFERENCES}

Bagdade, J. D., Bierman, E. L., and Porte, D. (1967). J. clin. Invest., 46, 1549 (The significance of basal insulin levels in the evaluation of the insulin response to glucose in diabetic and nondiabetic subjects). 
Bartels, E. G., Balodimos, M. C., and Corn, L. R. (1960). Med. Clin. Amer., 44, 433 (The association of gout and diabetes mellitus).

Beckett, A. G., and Lewis, J. G. (1960). Quart. J. Med., n.s. 29, 443 (Gout and the serum uric acid in diabetes mellitus).

Bendersky, G., and Kreithen, H. Unpublished data cited by Padova and Bendersky (1962).

Brøchner-Mortensen, K. (1958). Ann. rheum. Dis., 17, 1 (Heberden oration: Gout).

Buchanan, K. D., and McKiddie, M. T (1967). Clin. chim. Acta, 15, 315 (Experience with the immunoprecipitation technique of insulin assay with reference to sensitivity, precision and specificity)

Charcot, J. M. (1881). "Clinical Lectures on the Diseases of Old Age”, trans. L. Hunt, p. 75. Wood, Baltimore

Hales, C. N., and Randle, P. J. (1963). Biochem. J., 88, 137 (Immunoassay of insulin with insulinantibody precipitate).

Joslin, E. P., Root, H. F., White, P., and Marble, A. (1952). “The Treatment of Diabetes Mellitus", 9th ed., p. 93. Lea and Febiger, Philadelphia.

Kuzell, W. C., Schaffarzick, R. W., Naugler, W. E., Koets, P., Mankle, E. A., Brown, B., and Champlin, B. (1955). J. chron. Dis., 2, 645 (Some observations on 520 gouty patients).

McKiddie, M. T., Jackson, I. M. D., and Buchanan, K. D. (unpublished observations).

Mikkelsen, W. M. (1965). Arthr. and Rheum., 8, 853 (The possible association of hyperuricemia and/or gout with diabetes mellitus).

Padova, J., and Bendersky, G. (1962). New Engl. J. Med., 267, 530 (Hyperuricemia in diabetic ketoacidosis).

Prior, I. A. M., and Davidson, F. (1966). N.Z. med. J., 65, 375 (The epidemiology of diabetes in Polynesians and Europeans in New Zealand and the Pacific).

- , Rose, B. S., Harvey, H. P. B., and Davidson, F. (1966). Lancet, 1, 333 (Hyperuricaemia, gout, and diabetic abnormality in Polynesian people).

Talbott, J. H. (1964). "Gout", 2nd ed., p. 145. Grune and Stratton, New York.

Umber, F. (1914). "Ernährung und Stoffwechselkrankheiten”, 2nd ed. Urban and Schwarzenberg, Berlin.

Weiss, T. E., Segaloff, A., and Moore, C. (1957). Metabolism, 6, 103 (Gout and diabetes).

Whitehouse, F. W., and Cleary, W. J., Jr. (1966). J. Amer. med. Ass., 197, 73 (Diabetes mellitus in patients with gout)

Whytt, R (1768). "The Works of Robert Whytt", p. 707. Becket, Edinburgh.

Le diabète sucré et la goutte

Les réponses du sucre sanguin et de l'insuline du plasma au glucose par voie buccale chez les malades obèses, goutteux et de poids normal

\section{RÉSUMÉ}

L'association possible d'anomalies de l'épreuve de la glycémie et de la goutte a été exploré.

Le taux de sucre sanguin après une surcharge de glucose de $50 \mathrm{~g}$. par voie buccale et à jeun était bien plus élevé chez les malades atteints de goutte que chez les témoins à poids normal.

Les goutteux aussi avaient tendance à avoir des taux plus élevés d'insuline dans le plasma pendant l'épreuve de la glycémie.

Quand les données chez les malades du même poids, goutteux ou obèses, étaient comparées, ces différences n'étaient pas évidentes.

Quand les taux d'acide urique sanguin étaient augmentés artificiellement chez les malades normo-uricémiques en donnant de l'ARN par voie buccale, aucun changement n'a été noté dans le métabolisme des hydrates de carbone et celui de l'insuline.

Il est conclu qu'aucun dérangement marqué dans le métabolisme des hydrates de carbone et dans celui de l'insuline n'est associé à une insuffisance métabolique causant l'hyperuricémie dans la goutte primaire, si compte est tenu de l'obèsité dont les malades goutteux sont atteints bien souvent.
Diabetes mellitus y gota

Reacciones de la insulinay del azúcar sanguineos a la glucosa suministrada por vía oral en pacientes de peso normal, obesos y gotosos

\section{SUMARIO}

Se ha explorado la posible asociación de anormalidades de pruebas de tolerancia a la glucosa oral y la gota. Los niveles de azúcar en la sangre al cabo de una carga oral de $50 \mathrm{~g}$. de glucosa y de aynno fueron significativamente más altos en pacientes con gota que testigos de peso normal.

Los sujetos gotosos tendieron también a mostrar niveles más altos de insulina en el plasma, durante las pruebas de tolerancia de glucosa.

Cuando los datos de pacientes gotosos fueron comparados con los obtenidos en sujetos obesos de peso igual estas diferencias no fueron evidentes. Cuando los niveles de ácido úrico de la sangre fueron elevados artificialmente en individuos normouricémicos mediante suministro de ARN, no se notó cambio alguno en el metabolismo de los carbohidratos y la insulina. Se llega a la conclusión de que ningún desorden significativo del metabolismo del carbohidrato y la insulina tiente relación con el defecto metabólico que causa hiperuricemia en la gota primaria, si se hace la debida concesión a la obesidad que a menudo presentan los pacientes gotosos. 